\title{
Shortcut Nitrification-Denitrification Coupled With Sulfide Oxidation In A Single Reactor
}

\author{
Bruna de S Moraes ${ }^{1 *}$, João G T Orrú ${ }^{2}$, Catarina C de Andrade ${ }^{3}$, Débora F Fonseca ${ }^{2}$ and Eugenio Foresti ${ }^{2}$
}

${ }^{1}$ Brazilian Bioethanol Science and Technology Laboratory (CTBE), Brazilian Center for Research in Energy and Materials (CNPEM), Rua Giuseppe Máximo Scolfaro, 10.000, Polo Il de Alta Tecnologia, Brazil

${ }^{2}$ Department of Hydraulics and Sanitation, School of Engineering of São Carlos (EESC), University of São Paulo (USP), Av. Trabalhador São-Carlense, 400, Centro, São Carlos, São Paulo, Brazil

${ }^{3}$ Laboratório de Tecnologia Ambiental, Instituto Tecnológico de Pernambuco (ITEP), Av. Professor Luiz Freire, 700, Cidade Universitária, Recife, Brazil

\begin{abstract}
Nitrogen removal coupled with sulfide oxidation may be a suitable option for the post-treatment of anaerobic reactor effluents that contain ammoniacal nitrogen, which must be nitrified, and sulfide, which could be used as an endogenous electron donor for autotrophic denitrification. This research proposes the application of shortcut nitrification-denitrification coupled with sulfide oxidation in a single reactor to remove nitrogen from effluents of anaerobic reactors treating domestic sewage.A fixed-bed sequencing batch reactor (FBSBR) was used, operating in 8-hour cycles, subjected to intermittent aeration and employing autotrophic denitrification using the sulfide present in the effluent, pretreated anaerobically, as an electron donor.Nitrite accumulation was observed after application of the sulfide shock load, which inhibited the nitriteoxidizing bacteria.However, it was difficult to establish denitrification via nitrite due to the toxicity of this compound to denitrifying microorganisms in the reactor. The low overall efficiency of nitrogen removal and various operational constraints indicated that autotrophic denitrification using sulfide in the FBSBR was not satisfactory.
\end{abstract}

Keywords: Shortcut Nitrification-denitrification; Sulfide; Sequencing fed-batch reactor; Immobilized cells; Nitrite

\section{Introduction}

Effluents produced by anaerobic treatment systems usually present legally acceptable levelsoforganic matter removal efficiency. However, the ammoniacal- $\mathrm{N}$ concentrations in these effluents can pose an environmental problem because this type of treatment cannot remove nutrients efficiently. Furthermore, sulfide production levels can be extremely harmful, depending on the concentration of sulfate present in the influent sewage to be treated by anaerobic technology. In this context, autotrophic denitrification coupled with sulfide oxidation is a suitable solution for treating anaerobic reactor effluents. In this case, sulfide can be used as an endogenous electron donor source, reducing post-treatment costs. It should be noted that, in order to be efficient, this application depends on further research about new reactor configurations and operating conditions. Reactors must allow for the partial nitrification of the effluent so as to preserve part of the sulfide for denitrification,because, under conditions of aerobiosis, sulfide is oxidized to sulfate and/or to sulfur compounds in intermediate states of oxidation.

In this context, sequencing batch reactors (SBRs) may constitute a viable and optimized alternative for post-treatment of anaerobic reactor effluents, because they allow nitrification and denitrification to take place in a single reactor. In theory, the fed batch operation would allow the sulfide present in the effluent to be available for denitrification even after the nitrification process, since it would involve the controlled input of wastewater. Therefore, the investigation of theoperating variables of these reactors would contribute to the possible feasibility of their application in the post-treatment of anaerobic reactor effluents.

Conventionally, SBRs are operated in sequential cycles comprising four stages: feeding, reaction, settling and liquid discharge. However, several operational strategies have been studied to optimize the performance of these reactors. Among them, the fed-batch feeding mode contributes to keep the concentration of the substrate inside the reactor at low levels, so that the feeding phase involves a longer period than that adopted conventionally.This strategy can improve the distribution of electron donors and, due to dilution, can also preventinhibition by the substrate $[1,2]$.

Another technology for removing nitrogen that stands out is shortcut nitrification-denitrification.In this process, the steps of nitration and subsequent reduction of nitrate to nitrite are eliminated, and hence,ammoniacal- $\mathrm{N}$ is oxidized only to nitrite. This significantly reducesthe operating costs due to savings in the energy source for aeration (a 25\% reduction in oxygen demand) and in the exogenous carbon source for denitrification (a $30 \%$ to $40 \%$ reduction in the carbon source) $[3,4]$. Furthermore, nitrification to nitrite may decrease the reaction time of both nitrification and denitrification and also reduce excessive sludge production $[5,6]$.

Nitrite accumulation occurs through the inhibition of nitriteoxidizing bacteria. These bacteria are inhibited mainly by the presence of free ammonia [4], but may also occur at low concentrations of oxygen in the medium [7], or with alternating nitrification and denitrification in the same reactor [3]. The $\mathrm{pH}$ and temperature are also important

*Corresponding author: Bruna de Souza Moraes, Brazilian Bioethanol Science and Technology Laboratory (CTBE), Brazilian Center for Research in Energy and Materials (CNPEM), Rua Giuseppe Máximo Scolfaro, 10.000, Polo II de Alta Tecnologia, P.O. Box 6170, Campinas, São Paulo 13083 - 970, Brazil, Tel: +55 (19) 3517-5011; E-mail: bruna.moraes@bioetanol.org.br

Received November 16, 2013; Accepted February 06, 2014; Published February 11,2014

Citation: de S Moraes B, Orrú JGT, de Andrade CC, Fonseca DF and Foresti E (2014) Shortcut Nitrification-Denitrification Coupled With Sulfide Oxidation In A Single Reactor. J Microb Biochem Technol 6: 087-095. doi:10.4172/19485948.1000127

Copyright: () 2014 de S Moraes B, et al. This is an open-access article distributed under the terms of the Creative Commons Attribution License, which permits unrestricted use, distribution, and reproduction in any medium, provided the original author and source are credited 
operational parameters for the control of microbial populations, due to their effect on the chemical equilibrium that controls the concentration of free ammonia. Bae et al. [4] observed maximum nitrite accumulation in a batch reactor operating at $\mathrm{pH} 8-9$ and a temperature of about $30^{\circ} \mathrm{C}$, using mixed biomass (suspended and immobilized). The initial ammonia concentration was $50 \mathrm{mg} \mathrm{N} \mathrm{L}^{-1}$, and $77 \%$ of the removed ammonium was converted into nitrite.

Although exhaustive research has focused on conventional nitrification and denitrification processes, including biological posttreatment in SBRs, there are gaps in the literature on autotrophic denitrification using sulfide as electron donor.The feasibility of applying this process toeffluents from anaerobic reactors treating sanitary sewage, using sulfide from the effluent itself, has already been confirmed $[8,9]$. However, coupling it to nitrification in a single reactor has not yet been extensively investigated, and research about it is scanty [10], particularly for the post-treatment of effluents from anaerobic reactors treating sanitary sewage [11].

This research investigated the feasibility of shortcut nitrificationdenitrification, coupled with sulfide oxidation in a single fixed-bed sequencing batch reactor with intermittent aeration, applied to the post-treatment of effluents from an anaerobic reactor treating domestic sewage.

\section{Material and Methods}

\section{Fixed-Bed Sequencing Batch Reactor (FBSBR)}

The FBSBR was the same as the one presented by Moraes et al. [11] (Figure 1), since thisstudy is the continuation of the operation of the reactor used in their work. The reactor was made of borosilicate glass and equipped with a mechanical stirrer composed of tworadial flow turbine impellers $3.0 \mathrm{~cm}$ in diameter. A perforated stainless steel basket was placed inside the reactor to hold the biomass immobilized on polyurethane foamcubes. The basket was shaped like a hollow cylinder and its central region contained the agitator shaft.The top of the reactor had two inlets of $2.0 \mathrm{~cm}$ internal diameter to accommodate dissolved oxygen (DO) and redox potential (ORP) microsensors. The micro-sensors were connected to a data acquisition block coupled to a computer. Monitoring data were obtained using the software developed by T \& S Equipamentos Eletrônicos (Brazil). Porous stones were placed at the bottom of the reactor for air dispersion. Aeration was provided by an aquarium aerator. Two pumps were used for filling and discharging the liquid (Figure 1).

\section{Wastewater and inoculum}

The reactor was fed with effluent from a UASB reactor treating synthetic substrate simulating domestic sewage, described by Torres [12]. This composition presents substances simulating the organic fractions of domestic sewage (proteins, carbohydrates and lipids) of easy and difficult degradation, as well as detergent as surfactant and nutrients and trace elements.After UASB treatment, the effluent was composed mostly of ammonium-N and remaining organic matter of difficult degradation. The effluent from UASB reactor was collected in a 21 liter container, stored at $4^{\circ} \mathrm{C}$, and pumped into the FBSBR in the fed-batch mode. The average concentration of influent ammoniacal- $\mathrm{N}$ and remaining organic matter was $40 \mathrm{mg} \mathrm{NH}_{4}^{+}-\mathrm{NL}^{-1}$ and $80 \mathrm{mg}$ COD $\mathrm{L}^{-1}$, respectively. Sodium bicarbonate was added separately $(500 \mathrm{mg}$ $\mathrm{CaCO}_{3} \cdot \mathrm{L}^{-1}$ on average) to meet the nitrification demand and to improve the buffering capacity of the effluent. The UASB reactor effluent was

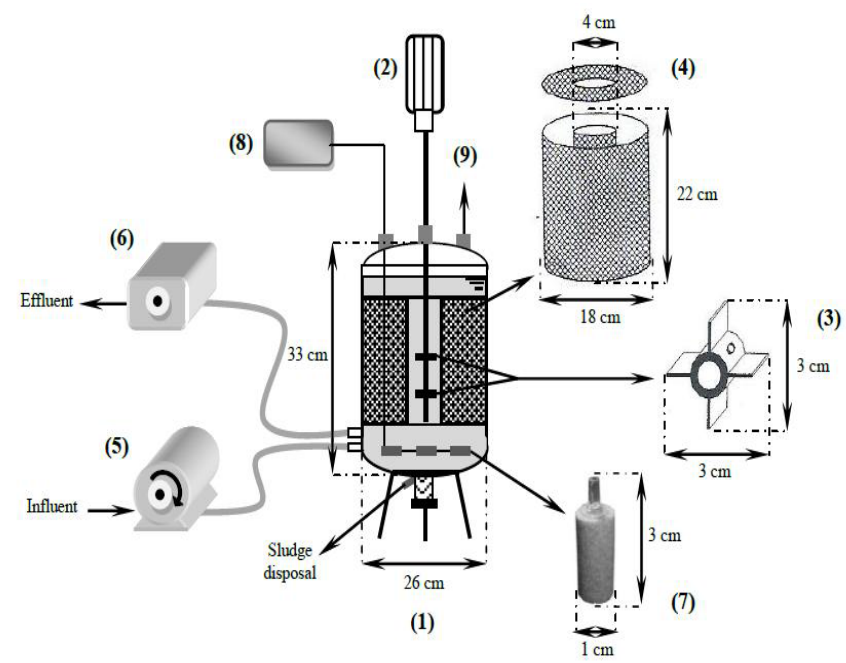

Figure 1: Schematic representation of the experimental setup: (1) crosssectional view of the nitrifying/denitrifying reactor operated in fed-batch mode (2) mechanical stirrer; (3) turbine impeller; (4) stainless steel basket; (5) peristaltic pump-feeding; (6) diaphragm pump-discharge; (7) porous stone; (8) aquarium air pump; (9) entry for micro-sensors.

free of sulfide, which was added separately as a sodium sulfide solution to allow for more precise control of the sulfide concentration in the reactor. This solution was kept in a sealed Duran flask $(1 \mathrm{~L})$ containing a bladder attached to the lid filled with $\mathrm{N}_{2}$ gas to prevent the chemical oxidation of this compound. The influent sulfide concentration varied

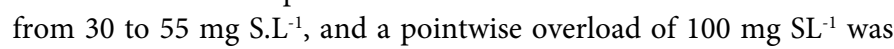
applied.

The inoculum was provided from Volkswagen's activated sludge system (São Carlos, SP, Brazil), presenting flocs with good settleability characteristics and composed of aerobic biomass, mainly bacteria (filamentous and flocs forming), protozoa and micrometazoan in equilibrium. Polyurethane foam cubes with $1.0 \mathrm{~cm}$ per side were used as supports to immobilize the biomass, following the procedure proposed by Zaiat et al.[13].

\section{Experimental procedure}

The reactor was operated in $8 \mathrm{~h}$ cycles, each consisting of two anoxic phases alternated with two aerated phases. The time of the cycles and the initial times of aerated/anoxic phases were defined according to the intrinsic kinetic parameters of sulfide-oxidizing autotrophic denitrification determined by Moraes and Foresti [14]. The cycles always started with an anoxic phase and ended with anaerated phase.The specific duration of each phase varied according to the operating conditions evaluated, which aimed at nitrite accumulation and autotrophic denitrification via nitrite. These conditions involved the overload of sulfide, adjustments in the duration of the aerated and nonaeratedphases, and variation of theconcentration of DO and $\mathrm{pH}$, as detailed in Table 1. Feeding was done in sequencing fed-batch mode only during the anoxic phases (intermittent feeding). The reactor was kept in an incubator at $30^{\circ} \mathrm{C}$ and the stirring was kept at $150 \mathrm{rpm}$ throughout the period of operation. The concentrations of nitrogen and sulfur compounds along the cycles, as well as the measured DO and ORP, were evaluated based on temporal profiles at the end of each experimental condition (Table 1). 


\section{Physicochemical analyses}

All the analyses were performed according to techniques described in the Standard Methods for the Examination of Water and Wastewater [15]. Chemical oxygen demand (COD) was determined by the colorimetric method and bicarbonate alkalinity (BA) by titration. Nitrate $\left(\mathrm{NO}_{3}^{-}-\mathrm{N}\right)$, nitrite $\left(\mathrm{NO}_{2}^{-}-\mathrm{N}\right)$ and sulfate $\left(\mathrm{SO}_{4}{ }^{2-}-\mathrm{S}\right)$ were determined by ion chromatography (ICS-5000, Dionex, USA). Ammonium- $\mathrm{N}\left(\mathrm{NH}_{4}^{+}-\mathrm{N}\right)$ was measured by flow injection analysis (FIA) and free ammonia was calculated according to Anthonisen et al. [16]. Total dissolved sulfide (TDS) was determined using the methylene blue colorimetric method. DO and ORP were measured with microsensors. Intermediate sulfur and nitrogen gas $\left(\mathrm{N}_{2}\right)$ compounds were estimated based on the principle of mass conservation.

\section{Quantification of nitrifying and denitrifying organisms}

The Most Probable Number (MPN) of nitrifying and denitrifying microorganisms was performed using serial dilutions from the attached biomass on polyurethane foam cubes, at the end of condition 1 and 4 . The foams were collected in order to be representative of the entire population of microorganisms present in the reactor. Samples were taken from the attached biomass foams with the aid of a glass rod and homogenized. All assays were performed in quintuplicates.

The quantification of nitrifying organisms involved the estimation of ammonia-oxidizing bacteriaand nitrite-oxidizing bacteria. The method of quantification was based on Focht and Joseph [17], modified by Tiedje [18] and adapted for liquid samples [19]. The quantification of denitrifying microorganisms was performed for heterotrophic bacteria and sulfide-oxidizing autotrophic bacteria. The methodology described by Tiedje [18] was applied for heterotrophic bacteria. For sulfideoxidizing autotrophic bacteria the method was based on Gevertz et al. [20] and Eckford and Fedorak [21], and the culture medium used was based on Moraes et al [8]. The MPNcounting of nitrifying and denitrifying bacteria was performed based on the combination of positive responses, by using the standard probability table described in Methods for the Examination of Water and Wastewater [15].

\section{Results and Discussion}

\section{Operational parameters}

The average values of the parameters monitored throughout the period of operation areshown in Table 2 and Figure 2, which provide an overview of the behavior of the analyzed compounds according to the evaluated conditions. It should be noted that the FBSBR operated previously for 180 days under conditions aimed at establishing autotrophic nitrification and denitrification via nitrate. The nitrification and denitrification efficiencies obtained in the experimental condition that preceded this assay were $85.7 \%$ and $53 \%$, respectively [11] (Table 2 and Figure 2).

During condition 1, the initial sulfide shock load (100 mg TDS $\left.\mathrm{L}^{-1}\right)$ was effective in directing nitrification only to nitrite, leading to

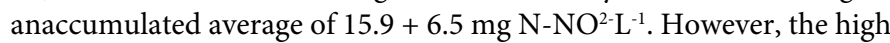
concentration of sulfide inhibited the nitrification process immediately after its application, drastically reducing its efficiency to about $14.5 \%$. After nine days from the application of the shock load,ammoniacal-N oxidation restarted with $89.9 \pm 0.9 \%$ of efficiency, indicatingthat the inhibition of nitrification caused by the presence of sulfide is a reversible process.Since the main product of nitrification was nitrite, nitriteoxidizing bacteria were significantly inhibited, probably by the release of free ammonia caused by high $\mathrm{pH}$ values during the application of the sulfide shock load ( 24 hours). In this period, the free ammonia concentration reached $26.4 \mathrm{mg} \mathrm{N}-\mathrm{NH}_{3} \mathrm{~L}^{-1}$ at the inlet of the reactor. Because the feeding strategy favored the dilution of the substrates, the concentration of free ammonia inside the reactor at the beginning of the cycles, during the application of shock loading, resulted in values of close to $11 \mathrm{mg} \mathrm{N}-\mathrm{NH}_{3} \mathrm{~L}^{-1}$, which is a much higher value than the inhibitory concentration presented by Abeling and Seyfried [22] (1-5 $\mathrm{mg} \mathrm{N}-\mathrm{NH}_{3} \mathrm{~L}^{-1}$ ).In this case, the ammoniacal-Noxidizing bacteria were also inhibited, since their inhibitory concentration lies in the range of 10 to $150 \mathrm{mg} \mathrm{N}-\mathrm{NH}_{3} \mathrm{~L}^{-1}[16]$.

The temporal profile of the nitrogen compounds drawn up after

\begin{tabular}{|c|c|c|c|c|c|c|}
\hline Condition & $\mathrm{pH}$ & $\begin{array}{c}\text { DO } \\
\left(\mathrm{mg} \mathrm{L}^{-1}\right)\end{array}$ & $\begin{array}{c}\mathbf{m g} \\
\operatorname{TDS}^{-1}-1\end{array}$ & Duration of phases (anoxic/aerated) & Feeding times/Total cycle time & $\begin{array}{c}\text { Feeding volume } \\
\text { /Total volume treated per cycle }\end{array}$ \\
\hline A1 & $8.0-9.0$ & 0.5 to 2.5 & 45 to 55 & $1 \mathrm{~h} 56^{\prime} / 1 \mathrm{~h} 56^{\prime}$ & B3h 52 '/8 h & $6.5 \mathrm{~L} / 4.3 \mathrm{~L}$ \\
\hline 2 & $8.0-9.0$ & 0.0 to 1.3 & 45 to 55 & $2 \mathrm{~h} \mathrm{06} / 1 \mathrm{~h} 46^{\prime}$ & B4h 12 '/8 h & $6.5 \mathrm{~L} / 4.3 \mathrm{~L}$ \\
\hline 3 & $8.0-9.0$ & 0.0 to 2.0 & 45 to 55 & $2 \mathrm{~h} \mathrm{22} / 1 \mathrm{~h} 30^{\prime}$ & B4h $44^{\prime} / 8 \mathrm{~h}$ & $6.5 \mathrm{~L} / 4.3 \mathrm{~L}$ \\
\hline 4 & 7.5 & 0.0 to 2.0 & 30 to 40 & 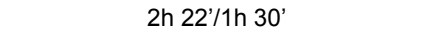 & B4h 44'/8 h & $6.5 \mathrm{~L} / 4.3 \mathrm{~L}$ \\
\hline
\end{tabular}

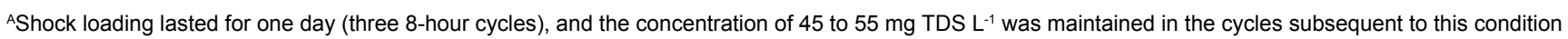
${ }^{\mathrm{B}}$ Corresponds to the duration of the two anoxic phases, since feeding was intermittent (only during the nonaerated phases)

Table 1: Description of the operating conditions applied to the FBSBR

\begin{tabular}{|c|c|c|c|c|c|c|}
\hline \multirow{2}{*}{ Condition } & \multirow{2}{*}{ Period of operation (d) } & \multicolumn{5}{|c|}{ INFLUENT } \\
\hline & & COD (mg L-1) & $\mathrm{AB}\left(\mathrm{mg} \mathrm{CaCO} \mathrm{L}^{-1}\right)$ & pH & TDS (mg S L-1) & $\mathrm{SO}_{4}^{-2}\left(\mathrm{mg} \mathrm{S} \mathrm{L}^{-1}\right)$ \\
\hline 1 & 181 to 220 & $89.3 \pm 12.0$ & $623.4 \pm 98.0$ & $8.9 \pm 0.3$ & $45.3 \pm 21.6$ & $10.9 \pm 6.1$ \\
\hline 2 & 221 to 246 & $72.1 \pm 13.2$ & $589.2 \pm 92.8$ & $8.9 \pm 0.3$ & $37.9 \pm 15.1$ & $14.5 \pm 5.0$ \\
\hline 3 & 247 to 259 & $81.3 \pm 15.4$ & $573.7 \pm 75.0$ & $9.1 \pm 0.2$ & $52.8 \pm 15.8$ & $23.5 \pm 7.3$ \\
\hline 4 & 260 to 270 & $73.5 \pm 10.1$ & $254.8 \pm 129.0$ & $7.7 \pm 0.6$ & $16.0 \pm 6.2$ & $14.9 \pm 6.4$ \\
\hline \multirow{2}{*}{ Condition } & \multirow{2}{*}{ Period of operation (d) } & \multicolumn{5}{|c|}{ EFFLUENT } \\
\hline & & $\operatorname{COD}\left(\mathrm{mg} \mathrm{L}^{-1}\right)$ & $\mathrm{AB}\left(\mathrm{mg} \mathrm{CaCO} \mathrm{L}^{-1}\right)$ & $\mathrm{pH}$ & TDS (mg S L-1) & $\mathrm{SO}_{4}^{-2}\left(\mathrm{mg} \mathrm{S} \mathrm{L}^{-1}\right)$ \\
\hline 1 & 181 to 220 & $34.4 \pm 10.9$ & $353.9 \pm 93.6$ & $8.1 \pm 0.1$ & $0.0 \pm 0.1$ & $26.8 \pm 7.3$ \\
\hline 2 & 221 to 246 & $26.5 \pm 15.1$ & $387.9 \pm 49.6$ & $7.9 \pm 0.2$ & $0.0 \pm 0.1$ & $35.2 \pm 14.6$ \\
\hline 3 & 247 to 259 & $33.0 \pm 7.8$ & $389.5 \pm 29.7$ & $8.2 \pm 0.2$ & $0.0 \pm 0.1$ & $65.0 \pm 14.5$ \\
\hline 4 & 260 to 270 & $27.2 \pm 1.8$ & $34.1 \pm 88.3$ & $6.7 \pm 0.7$ & $0.0 \pm 0.0$ & $33.8 \pm 4.6$ \\
\hline
\end{tabular}

Table 2: Mean values of the monitored parameters, divided according to the evaluated conditions. 
the process appeared to become stable revealed that concentrations of free ammonia remained within the inhibitory range only for the nitriteoxidizing bacteria (Figure 3a), with accumulation of this compound in the reactor.Moreover, theDO/N-NH and $\mathrm{DO} / \mathrm{N}-\mathrm{NH}^{4+}$ ratios also favored nitrite accumulation. According to Çeçen [7], $\mathrm{DO} / \mathrm{N}-\mathrm{NH}_{3}$ and $\mathrm{DO} / \mathrm{N}-\mathrm{NH}^{4+}$ ratios less than 10 and 1 , respectively, favor nitrification only to nitrite. In this research, the values of these ratios were in the range described by the above author, as shown in Figure $3 \mathrm{~b}$, confirming the existence of favorable conditions for nitrite accumulation (Figure 3 ).

Denitrification remained negligible during most of the period. The $\mathrm{N}_{2}$ values calculated during condition 1 revealed a highly unstable denitrification process $\left(4.3+5.6 \mathrm{mg} \mathrm{N}_{2}-\mathrm{N} \mathrm{L}^{-1}\right)$, even after the recovery of the nitrification process. The denitrifying biomass adapted to the use of nitrate as electron acceptor (previous condition, presented by Moraes et al. [11]) was probably inhibited by the presence of higher concentrations of nitrite, as reported by Jing et al. [23]. The authors evaluated the application of sulfide shock loads in the range 520 to 1820 mg S L ${ }^{-1}$ in aUASB reactor $(1.3 \mathrm{~L})$ and observed nitrite accumulation from partial denitrification, caused by the inhibitory action of high sulfide concentrations. After the application of shock loads, the performance of the denitrification reactor was not restored immediately, and this was attributed to the presence of toxic intermediates such as nitrite. Other authors have also reported the toxic effects of nitrite on denitrification [24-26]. However, the toxic effect of nitrite does not prevent the denitrifying biomass from adapting to its use as electron acceptor, as indicated by previous reports in the literature about the process of autotrophic denitrification via nitrite [8,14,27]. Thus, nitrification inhibition caused by the presence of nitrite appears to be a reversible process.

Another hypothesis that may explain the reduction of denitrification activity is the inhibition resulting from the application of the sulfide

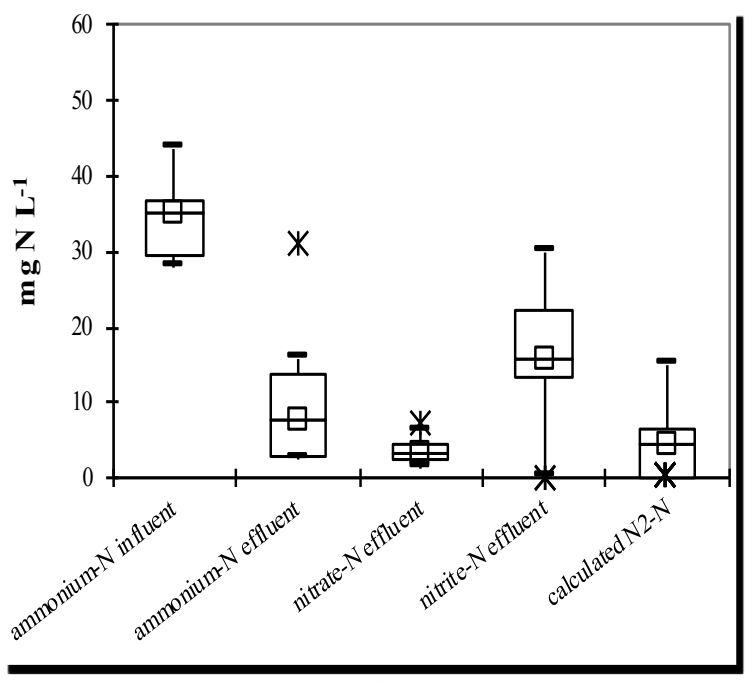

(a)

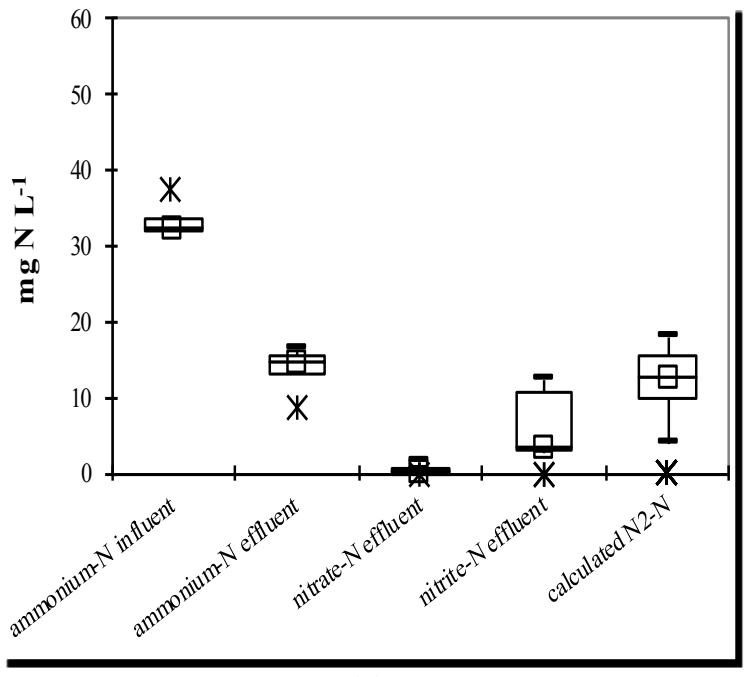

(c)

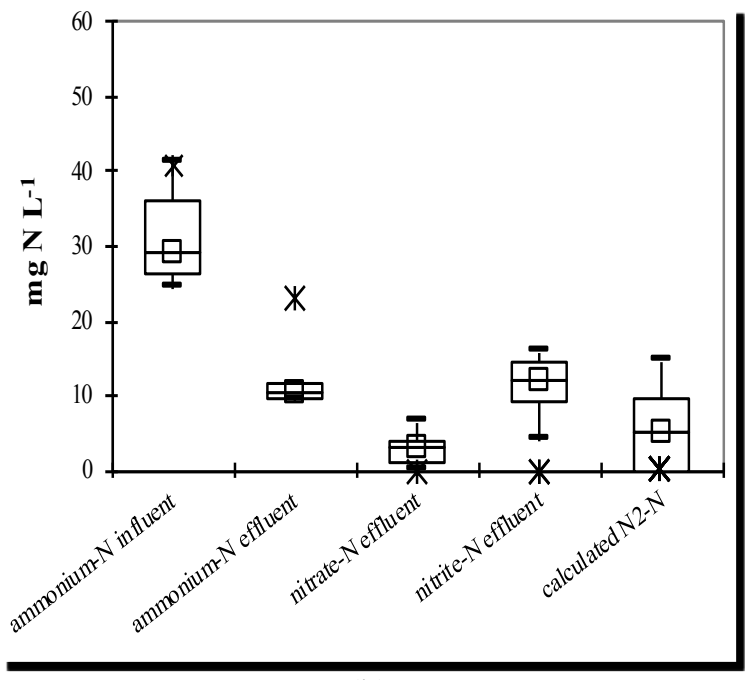

(b)

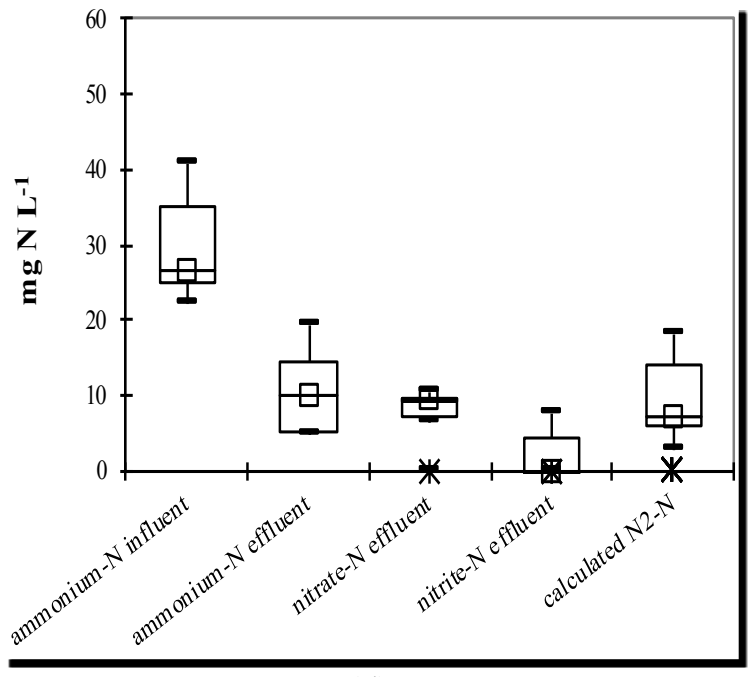

(d)

Figure 2: Concentration of nitrogen compounds in each monitored condition: (a) 1 (day 181to 220); (b) 2 (day 221 to 246 ); (c) 3 (day 247 to 259 ); (d) 4 (day 260 to 270). Data include inter-quartile deviation and median (larger box), ( $\square$ ) average value, (ж) outlier and ( - ) maximum (upper whisker) and minimum (lower whisker) limits of non-discrepant values. 


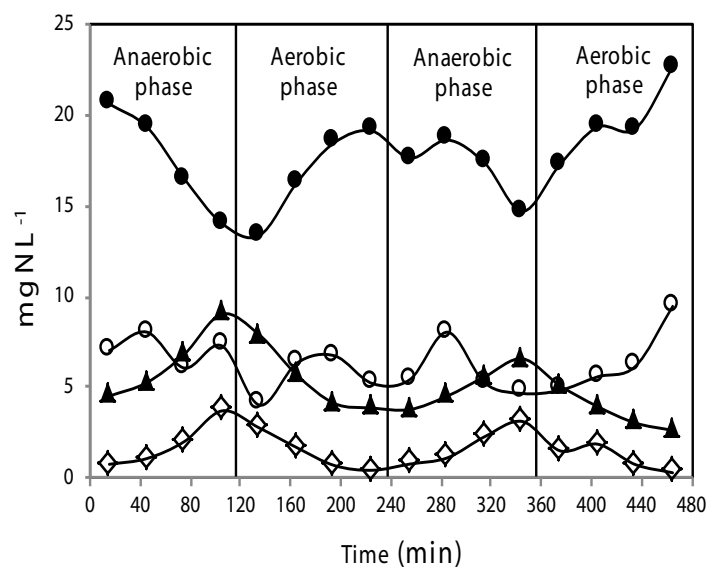

(a)

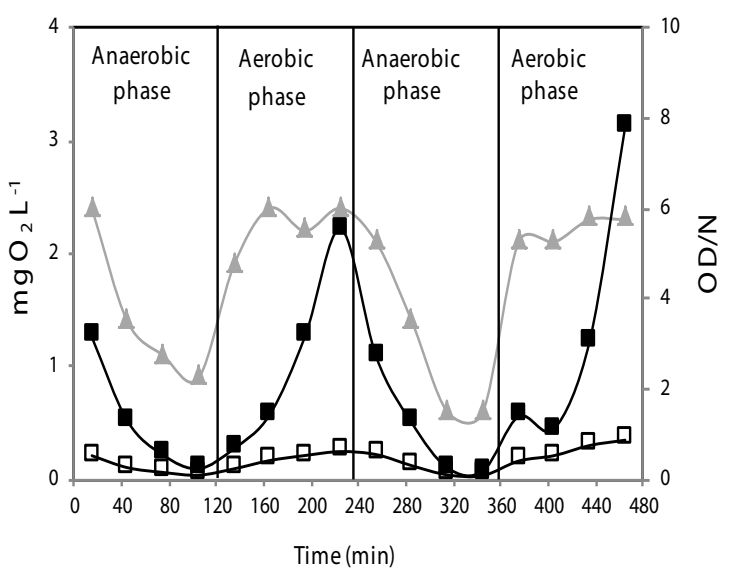

(b)

Figure 3: Temporal profile of a steady-state cycle $(8 \mathrm{~h})$ in condition 1, in terms of: (a) concentrations of nitrogen compounds: $(\boldsymbol{\Delta}) \mathrm{NH}^{4+}-\mathrm{N} ;(\diamond) \mathrm{NH}_{3}-\mathrm{N} ;(\circ) \mathrm{NO}^{3--} \mathrm{N} ;(\bullet)$

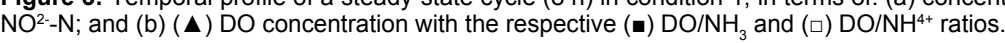

shock load (100 mg TDS $\mathrm{L}^{-1}$ ). However, this hypothesis was ruled out because the analyses performed immediately after this application indicated the occurrence of some denitrification activity (about $4.5+$ $0.8 \mathrm{~g} \mathrm{~N}_{2}-\mathrm{N} \mathrm{L}^{-1}$ were obtained), albeit with low nitrification efficiency. Moreover, some authors have reported the use of much higher concentrations of sulfide with no detrimental effect on denitrification $[23,28,29]$.

With regard to the electron donor, partial oxidation of sulfide occurred, and the formation and accumulation of a whitish substance characteristic of elemental sulfur was observed on the bottom of the reactor.There were also signs of elemental sulfur covering the lower part of the support that held the immobilized biomass. It should be noted that, in this condition, oxygen was being used preferentially as electron acceptor, since denitrification via nitrite was negligible but all the added sulfide was consumed (Table 2).

In view of these results, the next conditions were aimed adapting the denitrifying biomass to the presence of nitrite and establishing denitrification via nitrite, in an attempt to prevent oxygen from being the preferred electron acceptor. The ORPbehavior during thetemporal profile in the steady state indicated that the environment was not sufficiently favorable to the denitrification process, presenting values ranging from 90 to $150 \mathrm{mV}$ in the nonaerated phases, and 130 to 200 $\mathrm{mV}$ in the aerated phases. According to Wanner et al. [30], -50 to 50 $\mathrm{mV}$ is the ideal ORP value for denitrification, while 100 to $300 \mathrm{mV}$ is the ideal value for nitrification. Thus, it was decided to decrease the DO concentration in order to reduce the ORP of the liquid medium. Also, the duration of the nonaerated phase was increased by $10 \mathrm{~min}(2 \mathrm{~h} 06$ $\min )$.

The reactor was operated for 25 days in condition 2, during whichthe nitrification efficiency was found to decline from $89.9 \%$ to $59.9+12.0 \%$. Moreover, the nitrification process exhibited instability during this period, when it was strongly affected by the decreasein the DO concentration and by the 10 minutes of aerated phases $(1 \mathrm{~h} 46$ $\mathrm{min})$. The nitrate concentrations remained below $4 \mathrm{mg} \mathrm{NO}_{3}^{-}-\mathrm{N} \mathrm{L}^{-1}$, and the main product of nitrification was nitrite $\left(12.0+4.6 \mathrm{mg} \mathrm{NO}{ }^{-}-\mathrm{N}\right.$ $\left.\mathrm{L}^{-1}\right)$. The temporal profile of the nitrogen compounds at the end of this period indicated that a small part of nitrite was being consumed during the nonaerated phases. Therefore, little improvement in denitrification was observed when compared to condition 1, and on average only 4.9 $+5.6 \mathrm{mg}$ of $\mathrm{N}_{2}-\mathrm{N} \mathrm{L}^{-1}$ was denitrified.

The changes implemented in condition 2 were not effective in reducing the ORP values which were close to those attained in condition 1.In the aerated and nonaeratedphases, the ORP values ranged from 100 to $200 \mathrm{mV}$ and from 100 to $150 \mathrm{mV}$, respectively. The presence of oxidized compounds in the nonaerated phases, such as sulfate, nitrite and nitrate, contributed to keep the ORP values high, despite the decrease in DO concentration. Additionally, oxygen continued to act as the preferential electron acceptor for sulfide oxidation, since the entireamount of added sulfide was always consumed. The partial oxidation of sulfide to elemental sulfur was also detected again by visual evidence.However, this intermediate began to form in the feed hoses, as indicated by thelower influent concentration of sulfide, with a considerable standard deviation (Table 2), as a result of atmospheric oxygen entering through the connections of the feed hoses. Therefore, all the hose connections were changed, after which the partial oxidation of sulfide inside the hoses stopped.

In condition 3, the duration of the non-aerated phases was increased again by 16 minutes ( $2 \mathrm{~h} 22 \mathrm{~min})$. The DO concentration was also increased to improve the nitrification efficiency. However, the nitrification process continued to show low efficiencies throughout the period $(55.8+8.2 \%)$, due to the presence of higher concentrations of free ammonia inside the reactor, as well as the decrease in the aerated periods. On average, $10.5+2.5 \mathrm{mg} \mathrm{NH}_{3}-\mathrm{N} \mathrm{L}^{-1}$ was detected. As reported previously, free ammonia concentrations starting from $10 \mathrm{mg} \mathrm{NH}_{3}-\mathrm{N}$ $\mathrm{L}^{-1}$ inhibit ammoniacal-N oxidizing bacteria to some extent, impairing the oxidation of ammoniacal nitrogen [16]. This increase in thefree ammonia concentration was due to the increase in $\mathrm{pH}$, due to higher sulfide concentrations entering the reactor (Table 2). The highersulfide concentrations, in turn, were caused by the change of the feed hose connections, preventingsulfide oxidation prior to entering the reactor. However, partial oxidation of sulfide persisted inside the reactor, leading to the formation of elemental sulfur which was detected visually.

The denitrifying activity increased as the duration of nonaerated phases increased, reaching an average efficiency of $81.5+5.2 \%$ after one week of operation in condition 3 . Allied to this fact, the time elapsed up 
to this condition, counting from the period whennitrite accumulation started (74 days), probably allowed the denitrifying biomass to adapt to the presence of nitrite. Therefore, the duration of the operation also contributed to the occurrence of denitrification via nitrite.

Pérez et al. [10] reported nitrogen removal efficiency of over 95\% in a SBR using sulfide for autotrophic denitrification via nitrite. However, the authors used autotrophic denitrifying biomass preadapted to the process in the presence of sulfide, which was enriched in batch reactors. After detecting considerable denitrifying activity, this enriched sludge was mixed with the nitrifying biomass in the SBR.Even with this pre-selection of the biomass to the two processes (nitrification and denitrification) separately, shortcut nitrogen removal only stabilized after 30 days of operation. Therefore, the pre-selection of autotrophic denitrifying biomass using nitrite and sulfide as electron donor and acceptor, respectively, appears to be essential for the development of denitrificationvia nitrite with simultaneousnitrification in SBR reactors.

Mahmood et al. [31] reported 75\% nitrite removal efficiency after 15 days of operation in an upflow anoxic reactor applying stoichiometric concentrations of sulfide and nitrite. However, the sludge they used came from a methanogenic anaerobic reactor, and the operating conditions (an exclusively anoxic reactor, synthetic influent containing only nitrite as electron acceptor and sulfide as electron donor, under lithoautotrophic conditions for the establishment of denitrification) favored the development of autotrophic denitrifying biomass.

Mahmood et al. [27] also reported high nitrite removal efficiencies (78\%), using high concentrations of substrates $\left(1920 \mathrm{mg} \mathrm{NO}{ }^{-}-\mathrm{N} \mathrm{L}^{-1}\right.$ and $2265 \mathrm{mg}$ TDS $^{-1}$ ). In this case, the inoculated sludge also came from amethanogenic anaerobic reactor, previously enriched for 30 days todenitrification conditions in the presence of sulfide.

During all the operating conditions evaluated up to condition 3, adark precipitate was found to accumulate inside the hoses and at the bottom of the reactor, whose intensity varied according to the sulfide concentration used. The higher the sulfide concentration the greater the accumulation of this precipitate. This fact was attributed to iron precipitation by sulfide, forming iron sulfide, a dark brown or black chemical compound. The chemical characterization of this

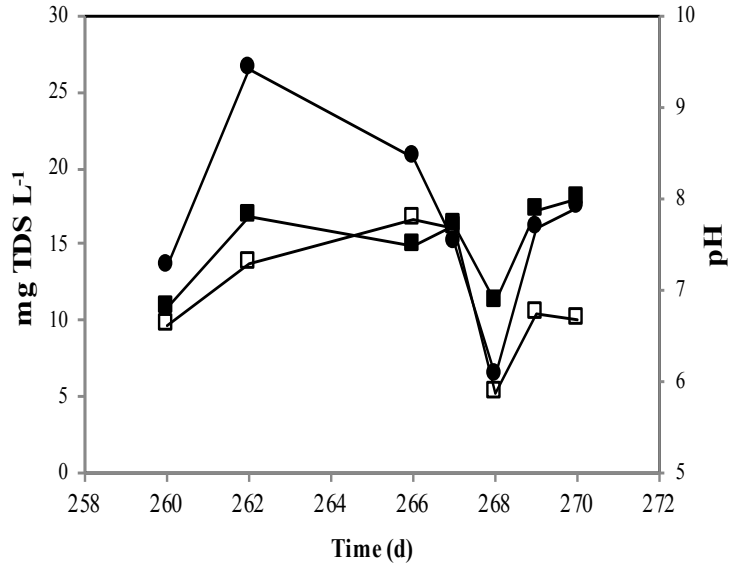

(a) precipitate by energy-dispersive X-ray spectroscopy (EDS) confirmed this hypothesis, and the elements sulfur, oxygen, iron, chromium and calcium in proportions of $34.0 \%, 54.3 \%, 2.0 \%, 3.6 \%$ and $6.1 \%$, respectively, were detected in the sample. Hence, precipitation of other trace elements such as calcium and chromium also occurred. Since these elements are essential for the activity of enzymes that catalyze the reactions involved in nitrification and denitrification [32], their precipitation by sulfide presumably contributed to the difficulty in establishing the two processes.

Since sulfide precipitation is enhanced as thepH increases, the high $\mathrm{pH}$ values measured in the FBSBR presumably contributed to the occurrence of this precipitation. In the $\mathrm{pH}$ range in which the reactor operated $(8-9)$, a large part of the sulfide would be in the form of $\mathrm{S} 2$, the chemical form in which precipitation occurs. Therefore, in condition 4 , the influent $\mathrm{pH}$ of the reactor was reduced to close to 7.5 , in an attempt to reduce precipitation. The sulfide concentration applied was also reduced to values close to stoichiometry relative to nitrite, considering only the portion of ammoniacal $\mathrm{N}$ that was being consumed $\left(\sim 20 \mathrm{mg} \mathrm{NH}{ }^{4+}-\mathrm{N} \mathrm{L}^{-1}\right)$. Therefore, about $18 \mathrm{mg}^{\mathrm{TDS} \mathrm{L}} \mathrm{L}^{-1}$ should be added.

The $\mathrm{pH}$ was adjusted by adding concentrated $\mathrm{HCl}$ to the container in which the effluent from the UASB reactor was collected.The final $\mathrm{pH}$ of this effluent was about 6.0, but when it was mixed with the concentrated sulfide solution prior to being fed into the FBSBR, the $\mathrm{pH}$ increased to approximately 7.5. However, the adjustment of the $\mathrm{pH}$ became completely dependent on the sulfide concentration. Therefore, reducing the sulfide concentration would also lower the $\mathrm{pH}$ of the influent entering the reactor.

Figure $4 \mathrm{a}$ shows the $\mathrm{pH}$ values as a function ofthe sulfide concentration. On day 268 a sharp drop in the concentration of sulfide fed into the reactor was observed, which was caused by the release of sulfide, in the form of gas, from the feed bottle. The bladder filled with $\mathrm{N}_{2}$ gas (100\%), which maintained the pressure inside the bottle, deflated during the night, causing the concentration of dissolved sulfide to decrease through the release of $\mathrm{H}_{2} \mathrm{~S}$, according to Henry's Law. Therefore, the $\mathrm{pH}$ of the influent liquid decreased to about 6 , while the effluent reached a lower value, affecting mainly the nitrification (Figure $4 b)$.

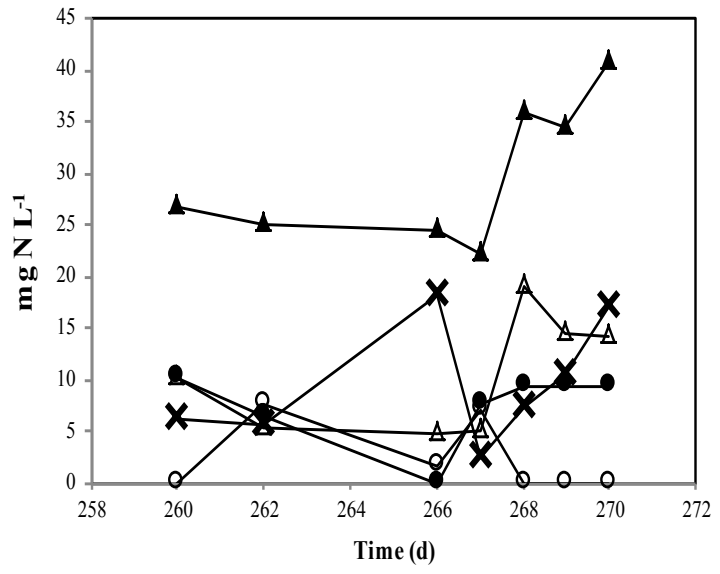

(b)

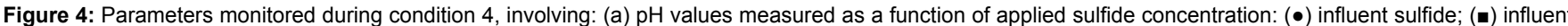
$\mathrm{pH}$ and ( $\square$ ) effluent $\mathrm{pH}$; (b) concentrations of nitrogen compounds: $(\Delta)$ influent $\mathrm{NH}^{4+}-\mathrm{N} ;(\Delta)$ effluent $\mathrm{NH}^{4+}-\mathrm{N} ;(\bullet)$ effluent $\mathrm{NO}^{3-}-\mathrm{N} ;(\bullet)$ effluent $\mathrm{NO}^{2-}-\mathrm{N} ;(\mathrm{x})$ calculated $\mathrm{N}_{2}-\mathrm{N}$. 
According to Fdz-Polanco et al. [33], at $\mathrm{pH}<6$, the activity of ammoniacal- $\mathrm{N}$ and nitrite-oxidizing bacteria decreases, even in the absence of free ammonia, but the quotient [ammoniacal-N oxidizing/ nitriteoxidizing bacteria] increases, causing nitrite to accumulate in the system. Jimenez et al. [34] also found that nitrite-oxidizing bacteria were inhibited at a $\mathrm{pH}$ of about 6.5. However, unlike their findings, we observed thatnitrate accumulated in the reactor, indicating the recovery of nitrite-oxidizing bacteria.Therefore, inhibition by free ammonia appeared to be the most important factor for reducing the activity of nitrite-oxidizing bacteria, since, in this condition, unlike the others, the concentration of free ammonia inside the reactor did not exceed $1.5 \mathrm{mg} \mathrm{NH}_{3}-\mathrm{N} \mathrm{L}^{-1}$ (Figure 4).

Nitrification efficiency remained satisfactory $(78.2+8.6 \%)$ in the period preceding the decline of the $\mathrm{pH}$ to 6 . In this period, the average $\mathrm{pH}$ at the inlet of the reactor was $7.6+0.4$ and bicarbonate alkalinity was sufficient $\left(370.0+45.8 \mathrm{mg} \mathrm{CaCO}_{3} \mathrm{~L}^{-1}\right)$. After the sharp drop in $\mathrm{pH}$, the efficiency decreased to $58.0+9.4 \%$, and on the day the $\mathrm{pH}$ dropped (day 268), the supplied alkalinity became insufficient $\left(89.3 \mathrm{mg} \mathrm{CaCO}_{3}\right.$ $\left.\mathrm{L}^{-1}\right)$, affecting the ammoniacal-N oxidizing bacteria. Even after the $\mathrm{pH}$ and alkalinity were recovered, the activity of these bacteria remained low.Carrera et al. [35] also found accumulation of ammoniacal-N due to the limited alkalinity in the system. However, nitrification was recovered by decreasing the nitrogen loading rate and controlling the $\mathrm{pH}$ at 7.5. It should be noted that in the present study, after the sharp drop in $\mathrm{pH}$, the reactor was monitored only for another 2 days. Therefore, the recovery of nitrification could not be evaluated, but it can be stated that this process showed signs of improvement, with a slight increase in efficiency from $46.7 \%$ to $65.4 \%$ on days 269 and 270 , respectively. On those days, the $\mathrm{pH}$ was about 7.9.

Denitrification remained unstable throughout the monitored period.As can be seen in Figure 4b, in general, when nitrite was formed, the calculated values of the concentration of $\mathrm{N}_{2}-\mathrm{N}$ formed were lower, reinforcing the hypothesis previously proposed (condition 1) about the inhibition of denitrification due to the presence of nitrite. This finding became more evidentstarting from day 268, when no nitrite concentration was formed, and denitrification efficiency improved from $43.5 \%$ to $64.6 \%$. In this case, the main product of nitrification was nitrate, and therefore, denitrification should occur from this compound rather than via the shortcut process. Hence, it was inferred that the denitrifying community established in the reactor would be betteradapted to use nitrate as electron acceptor, without the need for a long acclimatization period, as was observed in the case of shortcut nitrification (described in condition 3 ). Some authors have also reported the difficulty of using nitrite in denitrification due to the toxicity of this compound, specifically in the form of non-ionized nitrous acid [22,24].

\section{Nitrifying and denitrifying MPN quantification}

The estimated populations of nitrifying and denitrifying organisms performed at the end of specific operating conditions are presented in Table 3. The results allowed the monitoring of the microbiota behavior according to the operational changes it has undergone the FBSBR (Table 3)

It was detected the increasing of ammonia-oxidizing bacteria population by two orders of magnitude in the condition 1, while the nitrite-oxidizing bacteria decreased by an order of magnitude. This behavior was expected, since the purpose of this operating condition was the accumulation of nitrite in the reactor. With the reduction of nitrite-oxidizing bacteria, nitrification to nitrite prevailed. In this case, it was observed that the nitrite-oxidizing bacteria were more sensitive to high sulfide concentrations than ammonia-oxidizing bacteria Additionally, the results from operational conditions indicated the presence of free ammonia in inhibitory concentrations only for nitriteoxidizing bacteria, which is in accordance with MPN quantification.

In agreement with the operational results, the number of nitriteoxidizing bacteria grew considerably with decreasing $\mathrm{pH}$ (condition 4 ), and, consequently, with the reduction of free ammonia concentration. Therefore, the inhibition by the presence of free ammonia seemed to be the most important factor for the reduction of nitrite-oxidizing bacteria. On the other hand, the population of ammonia-oxidizing bacteria was not affected irreversibly by the $\mathrm{pH}$ reduction, not being hampered by the occasional occurrence of sudden drop of $\mathrm{pH}$ to about 6. According to the physical-chemical analysis, this fact has caused a reduction of about $30 \%$ of nitrifying activity due to insufficient alkalinity provided to the system. However, as reported by Carrera et al. [35], the alkalinity limitation does not cause irreversible damage to the activity of ammonium-oxidizing bacteria, which can be recovered in appropriate conditions for their development. Thus, the increase of this population can be related to its recovery during the incubation of MPN tubes.

In the case of denitrification, heterotrophic population decreased in the condition 4 , probably affected by the $\mathrm{pH}$ drop. However, there was an increase in the number of autotrophic denitrifying microorganisms by two orders of magnitude. According to the operational results, denitrification remained stable in this condition, but, even though, the denitrifying population developed itself. Therefore, when such autotrophic organisms were not using nitrate and/or nitrite as electron acceptors, they continued to develop with the use of oxygen, because some species of sulfur-oxidizing autotrophic microorganisms are facultative.

Overall, the cell counts indicated the constant presence of heterotrophic denitrifiers in the reactor. Thus, such microorganisms had effective participation in the denitrification, occurring concurrently with the autotrophic process. The COD consumption was observed during the whole period. Therefore, the non-readily degradableorganic matter present in effluent from UASB reactor (fed to FBSBR) would probably have supplied electrons to the occurrence of heterotrophic denitrification.

\begin{tabular}{|c|c|c|c|c|}
\hline \multirow{2}{*}{ Condition } & \multicolumn{2}{|c|}{ Nitrifying organisms (MPN mL-1) } & \multicolumn{2}{|c|}{ Denitrifying organisms (MPN mL-1) } \\
\hline & Ammonium oxidizing bacteria & Nitrite oxidizing bacteria & Heterotrophic & Autotrophic \\
\hline Alnitial & $9.2 \times 10^{16}$ & $7.8 \times 10^{7}$ & $4.7 \times 10^{16}$ & $1.4 \times 10^{5}$ \\
\hline 1 & $1.6 \times 10^{18}$ & $3.3 \times 10^{6}$ & $>1.6 \times 10^{18}$ & $1.7 \times 10^{5}$ \\
\hline 4 & $2.2 \times 10^{22}$ & $1.3 \times 10^{9}$ & $2.0 \times 10^{16}$ & $1.6 \times 10^{7}$ \\
\hline
\end{tabular}

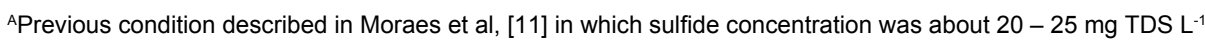

Table 3: MPN of nitrifying and denitrifying bacteria in FBSBR at the end of specific conditions. 


\section{Overview: main operational limitations}

The main limitation of FBSBR for nitrogen removal coupled with sulfide oxidation was the difficulty to providesulfide to the denitrifying process during nonaerated periods. DO was preferably used by microorganisms, due to its availability, to oxidize sulfide, undermining autotrophic denitrification. Additionally, favorable conditions for the development of autotrophic denitrification promoted decrease in the efficiency of the nitrifying process, being difficult to establish both processes in the same reactor. The pre-selection of such process in separate reactors, with their respective optimum environmental conditions, could have improved the overall nitrogen removal. Either way, the presence of sulfide revealed to be toxic to nitrifying bacteria. Fluctuations in sulfide concentration caused inhibition of nitrification process that, although reversible, hindered nitrogen removal. Thus, this type of reactor is not indicated for treatment of effluents with high or oscillatory sulfide concentrations, as this would result in the impairment ofnitrification and consequently denitrification.

This reactor configuration also promoted large accumulation of elemental sulfur and large consumption of alkalinity. Thus, alkalinity supplementation has become essential, which would raise the cost of post-treatment system. The accumulation of sulfur also required the regular cleaning of the reactor to avoid obstructions in the system.

Therefore, the main difficulties are related to the need for strict operational control of this system, and to the restriction regarding sulfide concentration of the wastewater. This fact could even derail your application because versatile, efficient and maintainable systems are clearly preferred.

\section{Conclusions}

Nitrite accumulation in the FBSBR was possible through the inhibition of nitrite-oxidizing bacteria, without impairing the oxidation of ammoniacal-N (partial nitrification). However, the use of nitrite by denitrifying micro-organisms in a diversified microbial community was hindered because they were subjected to adverse conditions which did not exclusively favor their selection. In general, the proposed application in the FBSBR promoted unsatisfactory nitrogen removal. Operational difficulties were encountered in establishing autotrophic denitrification using sulfide as electron donor coupled with nitrification in a single reactor, leading to a loss of efficiency in both processes. Therefore, different configurations of reactors and systems, or even some adjustments in the proposed reactor, might be more appropriate for the viability of this application to the post-treatment of effluents from anaerobic reactors.

\section{Acknowledgments}

This work was supported by FAPESP (Fundac ão de Amparo à Pesquisa do Estado de São Paulo) and CNPq (Conselho Nacional de Desenvolvimento Científico e Tecnológico). The authors would like to thank the technician responsible for the Laboratory of Advanced Treatment and Reuse Water (LATAR/ EESC-USP), Antônio Wagner Lamon, for the development and maintenance of the micro-sensors.

\section{References}

1. Tilche A, Bacieleri E, Bortone G, Malaspina F, Piccinini S, Stante L (1999) Biological phosphorus and nitrogen removal in a full scale sequencing batch reactor treating piggery wastewater. Water Sci Technol 40: 199-206.

2. Poo KM, Jun BH, Lee SH, Im JH, Woo HJ, et al. (2004) Treatment of strong nitrogen swine wastewater in a full-scale sequencing batch reactor. Water Sci Technol 49: 315-323.

3. Villaverde S (2004) Recent developments on biological nutrient removal processes for wastewater treatment. Rev Env Sci and Bio/Technol 3: 171-183.
4. Bae W, Baek S, Chung J, Lee Y (2001) Optimal operational factors for nitrite accumulation in batch reactors. Biodegradation 12: 359-366.

5. Turk O, Manivic DS (1989) Maintaining nitrite build-up in a system acclimated to free ammonia. Water Res 23: 1383-1388.

6. Alleman JE (1985) Elevated nitrite occurrence in biological wastewater treatment systems. Water Sci Technol 17: 409-19.

7. Çeçen $F$ (1996) Investigation of partial and full nitrification characteristics of fertilizer wastewater in a submerged biofilm reactor. Water Sci Technol 34: 77-85.

8. Moraes BS, Souza TS, Foresti E (2011) Characterization and kinetics of sulfideoxidizing autotrophic denitrification in batch reactors containing suspended and immobilized cells. Water Sci Technol 64: 731-738.

9. Moraes BS, Souza TSO, Foresti E (2012) Effect of sulfide concentration on autotrophic denitrification from nitrate and nitrite in vertical fixed-bed reactors. Proc Biochem 47: 1395-1401.

10. Pérez R, Galí A, Dosta J, Mata-Alvaréz J (2007) Biological nitrogen removal (BNR) using sulfides for autotrophic denitrification in a sequencing batch reactor (SBR) to treat reject water. Ind Eng Chem Res 46: 6646-6649.

11. Moraes BS, Orrú JG, Foresti E (2013) Nitrogen and sulfide removal from effluent of UASB reactor in a sequencing fed-batch biofilm reactor under intermittent aeration. J Biotechnol 164: 378-385.

12. Torres $P$ (1992) Performance of a bench-scale up-flow anaerobic sludge blanket (UASB) reactor for the treatment of synthetic substrate simulating domestic sewage. (In portuguese). 186p. Msc Thesis. School of Engineering of São Carlos (EESC), University of São Paulo (USP).

13. Zaiat M, Cabral AKA, Foresti E (1994) Fixed bed reactor for anaerobic wastewater treatment: design and preliminary evaluation of performance. (In Portuguese). Braz. J. Chem. Eng. 11: 33-42.

14. Moraes BS, Foresti E (2012) Determination of the intrinsic kinetic parameters of sulfide-oxidizing autotrophic denitrification in differential reactors containing immobilized biomass. Bioresour Technol 104: 250-256.

15. American Public Health Association/American Water Works Association/ Water Environment Federation (APHA/AWWA/WEF). 2005. Standard Methods for the Examination of Water and Wastewater, 21st ed. American Public Health Association/American Water Works Association/Water Environment Federation, Washington DC, USA.

16. Anthonisen AC, Loehr RC, Prakasam TB, Srinath EG (1976) Inhibition of nitrification by ammonia and nitrous acid. J Water Pollut Control Fed 48: 835852.

17. Focth DD, Joseph $H$ (1973). An improved method for the enumeration of denitrifying bacteria. Soil Sci Soc Ame J 37: 698-699.

18. Tiedje JM (1982) Denitrification. In: Page AL, Miller RH, Keeney DR (eds.) Methods of Soil Analysis, Amer Soc Agron, Madison, WI: 1011-1026.

19. Gianotti, EP, Santos, JE (1997) Denitrification in an oxibow lake in a floodplian of Mogi-Guaçu River: Infernão Lake, Jataí Ecological Station, state of São Paulo, Brazil. Verein Limnol 26: 305-308.

20. Gevertz D, Telang AJ, Voordouw G, Jenneman GE (2000) Isolation and characterization of strains CVO and FWKO B, two novel nitrate-reducing, sulfide-oxidizing bacteria isolated from oil field brine. Appl Environ Microbiol 66: 2491-2501.

21. Eckford RE, Fedorak PM (2002) Planktonic nitrate-reducing bacteria and sulfate-reducing bacteria in some western Canadian oil field waters. J Ind Microbiol Biotechnol 29: 83-92.

22. Abeling U, Seyfried CF (1992) Anaerobic-aerobic treatment of high-strength ammonium wastewater - nitrogen removal via nitrite. Water Sci Technol 26: 1007-1015.

23. Jing C, Ping Z, Mahmood Q (2009) Simultaneous sulfide and nitrate removal in anaerobic reactor under shock loading. Bioresour Technol 100: 3010-3014.

24. Glass C, Silverstein J, Oh J (1997) Inhibition of denitrification in activated sludge by nitrite. Water Environ Res 69: 1086-1093.

25. Chen Y, Cheng JJ, Creamer KS (2008) Inhibition of anaerobic digestion process: a review. Bioresour Technol 99: 4044-4064. 
Citation: de S Moraes B, Orrú JGT, de Andrade CC, Fonseca DF and Foresti E (2014) Shortcut Nitrification-Denitrification Coupled With Sulfide Oxidation In A Single Reactor. J Microb Biochem Technol 6: 087-095. doi:10.4172/1948-5948.1000127

26. Jing C, Ping Z, Mahmood Q (2010) Influence of various nitrogenous electron acceptors on the anaerobic sulfide oxidation. Bioresour Technol 101: 29312937.

27. Mahmood Q, Zheng P, Cai J, Wu D, Hu B, et al. (2007) Anoxic sulfide biooxidation using nitrite as electron acceptor. J Hazard Mater 147: 249-256.

28. Vaiopoulou E, Melidis P, Aivasidis A (2005) Sulfide removal in wastewater from petrochemical industries by autotrophic denitrification. Water Res 39: 41014109.

29. Manconi I, Carucci A, Lens P (2007) Combined removal of sulfur compounds and nitrate by autotrophic denitrification in bioaugmented activated sludge system. Biotechnol Bioeng 98: 551-560.

30. Wanner J (1991) Use of the routine biological analysis to check the performance of sewage treatment plants. Proceedings of the International Symposium on Biological Approach to Sewage Treatment Process: Current Status and Perspectives.

31. Mahmood Q, Zheng P, Cai J, Wu D, Hu B, Islam E, Azim MR (2007) Anoxic sulfide biooxidation using nitrate/nitrite as electron acceptor. Environ Prog 26 169-177.

32. Richardson DJ, Watmough NJ (1999) Inorganic nitrogen metabolism in bacteria. Curr Opin Chem Biol 3: 207-219.

33. Fdz-Polanco F, Villaverde S, Garcia PA (1996) Nitrite accumulation in submerged biofilters - combined effects. Water Sci Technol 34: 371-378.

34. Jiménez E, Giménez JB, Ruano MV, Ferrer J, Serralta J (2011) Effect of pH and nitrite concentration on nitrite oxidation rate. Bioresour Technol 102: 8741 8747.

35. Carrera J, Vicent T, Lafuente J (2004) Effect of influent COD/N ratio on biological nitrogen removal (BNR) from high strength ammonium industrial wastewater. Proc Biochem 39: 2035-2041. 